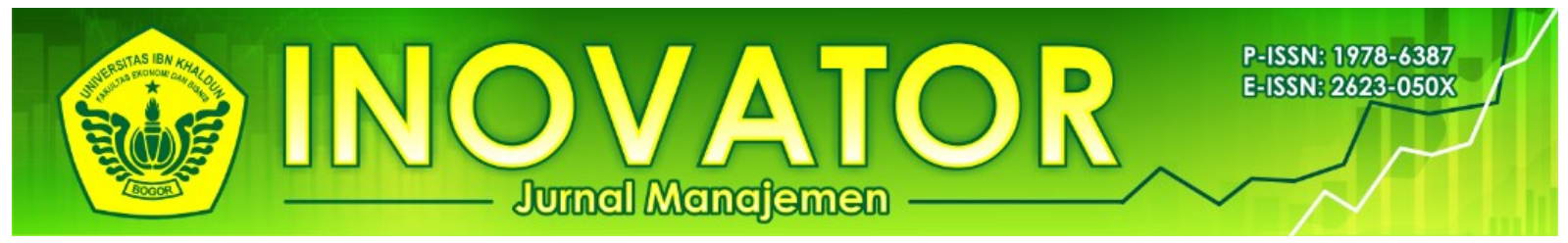

\title{
Profitabilitas Terhadap Nilai Perusahaan Dengan Intellectual Capital Sebagai Variabel Moderasi
}

\author{
Muchammad Arie Wibowo dan Indah Yuliana
}

Jurusan Manajemen, Fakultas Ekonomi, Universitas Islam Negeri Maulana Malik Ibrahim Malang

Jl. Gajayana No.50, Malang, 65144, Indonesia.

\begin{tabular}{ll}
\hline Info Artikel & \multicolumn{1}{c}{ Abstraksi } \\
\cline { 1 - 2 } Kata Kunci: & Penelitian ini bertujuan untuk menguji pengaruh dari profitabilitas terhadap \\
Intellectual Capital; Nilai & nilai perusahaan dan juga untuk mengetahui efek intellectual capital sebagai \\
perusahaan, dan & variabel moderasi pada hubungan antara profitabilitas terhadap nilai perusahaan. \\
Profitabilitas & Populasi penelitian ini adalah perusahaan yang tergabung dalam indeks LQ45 \\
& periode 2016-2018. Pemilihan sampel menggunakan teknik purposive sampling. \\
& Jumlah data analisis sebanyak 60 pasang data. Teknik analisis data yang \\
& digunakan adalah analisis regresi moderasi (MRA). Hasil penelitian menunjuk- \\
& kan bahwa profitabilitas memiliki pengaruh positif terhadap nilai perusahaan \\
ISSN (print): 1978-6387 & pada perusahaan LQ45 dan intellectual capital dapat memoderasi hubungan an- \\
ISSN (online): 2623-050X & tara profitabilitas terhadap nilai perusahaan pada perusahaan LQ45 periode \\
& 2016-2018
\end{tabular}

\section{Abstract}

Keywords:

Firm Value; Intellectual capital, and Profitability

Korespondensi Penulis:

Muchammad Arie Wibowo

Email:

ariewibowo1234@gmail.com

This study aims to examine the effect of profitability on firm value and also to determine the effect of intellectual capital as a moderating variable on the relationship between profitability and firm value. The population of this study are companies that are members of the LQ45 index for the 2016-2018 period. The sample selection used purposive sampling technique. The amount of data analyzed was 60 pairs of data. The data analysis technique used is moderated regression analysis (MRA). The results show that profitability has a positive influence on firm value in LQ45 companies and intellectual capital can moderate the relationship between profitability and firm value in LQ45 companies for the 20162018 period.

\section{Pendahuluan}

Investasi dalam hakikatnya dilakukan oleh penanam modal dengan tujuan untuk memperoleh tambahan dana dari yang ditanamkan di masa kini yang akan diambil di masa yang akan datang (Halim, 2005:4). Ada dua tujuan seorang investor melakukan investasi yakni deviden atau capital gain. Sebelum melakukan suatu investasi investor akan memerlukan semua informasi terkait dengan perusahaan yang akan dijadikan tempat investasinya (Yanti, 2013). Informasi diperlukan sebagai bahan analisis investor. Investor akan 
berupaya menekan risiko dan mengoptimalkan return investasinya.

Informasi-informasi yang dibutuhkan oleh investor atau masyarakat yang ada di luar perusahaan bisa didapatkan dengan mudah di dalam laporan keuangan perusahaan. Tujuan dari perusahaan membuat laporan keuangan adalah untuk menyampaikan seluruh informasi yang berguna bagi para investor dalam hal menilai kemampuan manajemen suatu perusahaan dalam mengatur sumber daya yang ada dalam perusahaan secara efektif agar sasaran atau target yang menjadi tujuan perusahaan dapat tercapai (Belkaoui, 2006).

Laporan keuangan merupakan informasi penting terkait dengan kinerja perusahaan. Kinerja manajemen perusahaan tersebut tercermin pada laba yang terkandung dalam laporan laba rugi. Laba dalam laporan keuangan bisa dilihat dengan berbagai rasio keuntungan atau rasio profitabilitas. Perusahaan dengan laba yang tinggi mengindikasikan profitabilitasnya semakin tinggi (Chandrarin \& Cahyaningsih, 2018). Rasio profitabilitas dapat diartikan sebagai hasil dari berbagai kebijakan atau keputusan yang diambil oleh manajemen dalam mengelola perusahaannya (Husnan \& Pudjiastuti, 2002: 56). Profitabilitas juga bisa diartikan sebagai keuntungan perusahaan yang berasal dari penjualan yang dilakukan (Astuti, 2004: 36). Profitabilitas perusahaan merupakan cerminan dari kinerja perusahaan (Haryanto et al., 2018).

Perusahaan yang mampu menghasilkan laba yang tinggi menunjukkan pengelolaan manajemen dalam menghasilkan keuntungan dari sumber daya yang dimiliki oleh perusahaan semakin baik. Kondisi ini membuat persepsi investor terhadap perusahaan tersebut juga baik, sehingga harga saham perusahaan tersebut meningkat (Sari \& Abundanti, 2014,).

Kinerja keuangan perusahaan merupakan sinyal penting bagi investor (McGuire, Schneeweis, \& Branch, 1990; Haryanto, 2014; Chen, Ezzamel, \& Cai, 2011; Azeez, 2015; Haryanto, 2016; Hamdan, 2018; Fristiani, Pangastuti, \& Harmono, 2020; Banamtuan, Zuhroh, \& Sihwahjoeni, 2020)). Seorang investor dalam melakukan investasi pasti meng- harapkan adanya pengembalian dana dengan keuntungan yang diharapkannya, dimana keuntungan perusahaan yang tinggi atau kemampuan perusahaan mencetak laba semakin baik semakin besar pula return yang diharapkan sehingga secara otomatis nilai perusahaan pun juga akan meningkat.

Nilai perusahaan adalah harga yang mampu dibayarkan oleh calon investor ketika perusahaan tersebut dijual (Husnan, 2013: 7). Menurut Sudana (2015: 9) faktor laba adalah salah satu faktor terpenting dalam nilai perusahaan, ini diakibatkan perusahaan yang berorientasi pada laba akan selalu meningkatkan bagaimana pengelolaan sumber daya yang dimilikinya akan maksimal. Ketika suatu perusahaan telah menjadi perusahaan terbuka atau telah menawarkan sahamnya ke publik maka nilai perusahaan bisa diartikan sebagai perspektif investor terhadap perusahaan tersebut.

Investor dapat menggunakan nilai perusahaan untuk menilai dan melihat kinerja suatu perusahaan di masa yang akan datang, dimana harga saham biasanya dikaitkan dengan nilai perusahaan. Investor akan mendapatkan keuntungan apabila harga saham perusahaan tinggi. Harga saham yang tinggi berbanding lurus dengan nilai perusahaan yang tinggi juga (Wijaya \& Sedana, 2015). Nilai perusahaan yang tinggi membuat rasa percaya seorang investor kepada perusahaan tersebut juga tinggi. Nilai perusahaan dapat dilihat dengan berbagai cara salah satunya adalah price to book value. PBV menunjukkan seberapa jauh perusahaan mampu menciptakan nilai perusahaan dibandingkan dengan jumlah saham yang dijual oleh perusahaan tersebut. Dengan mengetahui PBV para investor dapat menilai perusahaan tersebut apakah sudah bernilai wajar, terlalu murah, atau justru terlalu mahal. Perhitungan PBV dilakuan dengan membandingkan total modal atau ekuitas yang dimiliki oleh perusahaan dibandingkan dengan jumlah saham yang beredar.

Profitabilitas dan informasi lain yang tercermin dari perusahaan yang digunakan oleh investor dalam melakukan keputusan investasi. Informasi yang disampaikan manajemen 
merupakan sinyal bagi investor, yang akan berpegaruh pada nilai perusahaan. Hal ini sejalan dengan signalling theory. Signalling theory bisa diartikan sebagai alat untuk mengetahui pengaruh informasi yang disediakan oleh perusahaan terhadap perspektif investor (Brigham \& Brigham, Eugene F., \& Joel, 2001). Asumsi dasar penggunaan teori signalling adalah informasi yang ditangkap oleh para pihak yang berkepentingan tidak lah sama karena sifat investor satu dengan investor yang lainnya juga tidak sama. Contoh sederhana dari signalling theory adalah laporan laba perusahaan tahun berjalan meningkat dari tahun sebelumnya maka laporan laba tersebut diinterpretasikan sebagai kabar baik dan sebaliknya apabila laporan laba tahun berjalan menurun dari pada tahun sebelumnya maka laporan laba tersebut diinterpretasikan menjadi kabar buruk.

Profitabilitas dalam penelitian ini diukur menggunakan rasio ROA dan ROE karena rasio ROA ini bisa mencerminkan kualitas pengelolaan manajemen dalam perusahaan dalam mengelola semua aset yang dimiliki oleh perusahaan tersebut. Penggunaan rasio ROE dapat menilai kemampuan pengelolaan perusahaan terhadap total modal yang dimilikinya Jadi pengukuran profitabilitas apabila menggunakan variabel ROA dan ROE dapat mencerminkan kualitas pengelolaan perusahaan dari sisi aset dan modal yang sama-sama menjadi bagian penting dalam perusahaan.

Perusahaan dalam perkembangannya tidak mungkin hanya cukup mengandalkan aktiva berwujudnya saja. Aktiva tidak berwujud seperti sistem informasi, pengelolaan organisasi, inovasi, dan sumber daya manusia sebagai penggerak utama yang dimiliki oleh perusahaan pun juga ikut memegang peranan yang tidak kalah penting atas kelangsungan atau kontinuitas perusahaan. Untuk bersaing dengan perusahaan yang lainnya secara kompetitif, tidak sedikit perusahaan yang mengubah pola pengelolaan perusahaan menjadi perusahaan berbasis pengetahuan (knowledgebased business) dari yang awalnya perusahaan berbasis tenaga kerja (labor-based business) (Suwarjuwono \& Kadir, 2003).
Perusahaan berbasis tenaga kerja memegang prinsip dimana tenaga kerja adalah satu-satunya penggerak perusahaan dan penentu produktivtas perusahaan, semakin banyak tenaga kerja yang dimiliki oleh perusahaan maka semakin produktiflah pengelolaan sumber daya dan pencapaian penghasilan perusahaan. Berbeda dengan perusahaan penerap basis pengetahuan, perusahaan akan selalu berusaha menciptakan suatu cara atau teknik untuk mengelola pengetahuan sebagai sarana untuk memperoleh pendapatan dan keuntungan perusahaan.

Pendekatan yang digunakan dalam penilaian knowledge asset adalah intellectual capital (IC). Pengukuran IC dalam penelitian ini menggunakan metode yang dikembangkan oleh Pulic (2000) yakni metode Value Added Intellectual Coefficient (VAIC ${ }^{\mathrm{TM}}$ ) yang menyajikan informasi tentang value creation efficiency dari tangible asset dan intangible asset. VAIC ${ }^{\mathrm{TM}}$ merupakan instrumen untuk menghitung intellectual capital. Komponen dari VAIC ${ }^{\mathrm{TM}}$ adalah physical capital (VACA-Value Added Capital Employed), human capital (VAHU-Value Added Human Capital), dan structural capital (SCVAStructural Capital Value Added) (Ulum, 2009: 86; Fristiani, Pangastuti, \& Harmono, 2020).

Fenomena intellectual di indonesia mulai berkembang dengan munculnya pernyataan standar akuntansi keuangan (PSAK) no 19 tentang aktiva tidak berwujud. Menindaklanjuti hal tersebut banyak perusahaan yang menggunakan strategi bisnis berbasis pengetahuan bukan lagi basis tenaga kerja. Banyaknya perusahaan yang berbasis pengetahuan ditandai dengan adanya Most Admired Knowledge Enterprise (MAKE) Study yang dimulai pada tahun 2005. Indonesia MAKE Study merupakan suatu penghargaan terhadap perusahaan berbasis pengetahuan paling dikagumi di Indonesia. Dengan adanya Indonesia MAKE Study ini perusahaan di Indonesia dapat bersaing dengan menggunakan keunggulan kompetitif yang diperoleh melalui inovasi dan kreatifitas dalam menggunakan pengetahuan yang dimiliki perusahaan untuk menciptakan produkproduk yang lebih baik daripada sebelumnya.

Informasi penting bagi investor adalah in- 
tellectual capital. Perusahaan yang menginvestasikan pada intellectual capital semakin besar cenderung kana memiliki profitabilitas yang semakin tinggi dan akan memiliki prosepek yang semakin baik (Ozkan, Cakan, \& Kayacan, 2017; Hamdan, 2018; Elfiswandi, Pratiwi, \& Melmusi, 2019; Ramadhan, Abdurahim, \& Sofyani, 2019; Fristiani et al., 2020). Temuan penelitian terkait intellectual capital terhadap nilai perusahaan menunjukkan hasil yang belum konsisiten. Temuan penelitian Hamdan (2018) menunjukkan bahwa intellectual capital berpengaruh negatif terhadap kinerja berbasis pasar. Penelitian Buallay (2017) menunjukkan bahwa intellectual capital tidak berpengaruh terhadap kinerja operasional (ROA) perusahaan, namun berpengaruh positif terhadap kinerja keuangan (ROE). Penelitian Poh et al., (2018) dan Septiani, Holiawati, \& Ruhiyat (2019) menunjukkan bahwa intellectual capital berpengaruh terhadap nilai perusahaan.

Penelitian ini bertujuan untuk mengetahuio pengaruh profitabilitas terhadap nilai perusahaan, menganalisis intellectual capital nilai perusahaan dan profitabilitas terhadap nilai perusahaan dengan intellectual capital sebagai variabel moderator.

\section{Pengembangan Hipotesis}

\section{Profitabilitas terhadap nilai perusahaan}

Profitabilitas dapat diartikan sebagai salat satu rasio pengukuran keberhasilan perusahaan dalam menghasilkan laba dari sumber daya yang dimiliki oleh perusahaan (Fahmi, 2014: 60) Selain menjadi tolak ukur keberhasilan perusahaan secara historis dalam suatu periode akuntansi, rasio profitabilitas juga dapat dijadikan tolak ukur prospek peru-sahaan dimasa yang akan datang.

Semakin maksimal usaha perusahaan dalam pengelolaan sumber daya yang dimilikinya maka semakin baik pula tingkat profitabilitas perusahaan tersebut. Perusahaan dengan profitabilitas yang semakin tinggi menunjukkan perusahaan mampu mengeloa sumber daya yang dimiliki semakin efisien. Perusahaan dengan profitabilitas yang semakin tinggi mengindikasikan perusahaan terse- but sehat dan memiliki prospek yang baik. Profitabilitas yang semakin tinggi menjadi sinyal positif bagi investor akan prospek perusahaan di masa depan. Investor akan cenderung menginvestasikan ke perusahaan dengan profitabilitas yang tinggi, karena kemungkinan untuk memperoleh return menjadi lebih tinggi. Selain itu risiko investasinya akan lebih kecil. Sehingga harga saham akan cenderung meningkat pada perusahaan dengan profitabilitas yang semakin meningkat, ekspektasi investor akan semakin tinggi. Secara tidak langsung membuat nilai perusahaan tersebut meningkat. Teori ini sejalan dengan penelitian Chang \& Hsieh (2011); Dewi et al., (2014); Martini (2014), Wang Wang, \& Liang, (2014); Nurminda, Isynuwardhana, \& Nurbaiti (2017); Rudangga \& Sudiarta (2016); Mohammad \& Bujang, (2019); Xu \& Liu, 2020) yang menemukan bahwa profitabilitas berpengaruh positif signifikan terhadap nilai perusahaan.

$\mathrm{H}_{1}$ : Profitabilitas berpengaruh positif terhadap nilai perusahaan

\section{Moderasi Intellectual Capital pada hubungan Profitabilitas terhadap Nilai Perusahaan}

Profitabilitas dapat menjadi penilaian bagaimana manajemen internal memanfaatkan sumber daya yang dimiliki oleh perusahaannya (Fahmi, 2014: 81). Sumber daya perusahaan salah satu contohnya adalah aset perusahaan yang terdiri keuangan perusahaan, kendaraan, mesin, gedung, dan lain-lain. Seluruh aset tersebut tidak akan bisa berfungsi optimal tanpa didukung oleh sumber daya manusia yang berada di dalam perusahaaan. Selain adanya aset berwujud dalam perusahaan juga terdapat intellectual capital seperti teknologi dan pengetahuan yang bisa melahirkan inovasi baru.

Aset tidak berwujud itu bisa digunakan oleh perusahaan untuk mendapatkan keunggulan bersaing atau competitive advantage yang akan membuat keuntungan perusahaan bertambah (Kuspinta \& Husaini, 2018). Keuntungan dapat dinilai dengan profitabilitas dan secara tidak langsung hal itu dapat meningkatkan minat investor terhadap perusahaan. Yang menyebabkan harga saham perusahaan 
naik dan nilai perusahaan meningkat.

$\mathrm{H}_{2}$ : Intellectual Capital dapat memoderasi pengaruh profitabilitas terhadap nilai perusahaan

\section{Metode Penelitian}

Penelitian ini merupakan penelitian kuantitatif deskriptif. Populasi dalam penelitian ini adalah seluruh perusahaan yang konsisten masuk kedalam indeks LQ45 di Bursa Efek Indonesia pada tahun 2016-2018. Teknik pengambilan sampel yang digunakan adalah purposive sampling method. Kriteria sampel adalah perusahaan yang selalu konsisten berada dalam indeks LQ45 dari tahun 2016-2018, tidak pernah mencatatkan kerugian selama periode penelitian, dan perusahaan dengan data penelitian lengkap hingga diperoleh 20 perusahaan. Perusahaan yang menjadi sampel penelitian sebanyak 20 perusahaan.

Variabel bebas yaitu profitabilitas diukur dengan ROA dan ROE. Dimana ROA diukur dengan nisbah laba bersih terhadap total aset perusahaan dan ROE diukur dengan nisbah antara laba bersih terhadap total ekuitas untuk ROE.

$$
\begin{aligned}
& (\text { ROE })=\frac{E A T)}{(\text { Total Equity }} \\
& (\text { ROE })=\frac{\text { EAT })}{(\text { Total Equity }}
\end{aligned}
$$

Variabel terikat dalam penelitain ini adalah nilai perusahaan yang diukur dengan variabel Price to Book Value (PBV) karena PBV menunjukkan besarnya reaksi pasar dalam menghargai nilai buku saham suatu perusahaan. PBV dihitung dengan rumus sebagai berikut:

$$
P B V=\frac{(\text { Harga Pasar Per Lembar })}{(\text { Nilai Buku Per Lembar Saham })}
$$

Variabel moderasi yaitu variabel Intellectual Capital. Intellectual capital diukur menggunakan metode $\mathrm{VAIC}^{\mathrm{TM}}$ dengan rumus sebagai berikut:

$$
V A I C^{T M}=V A C A+V A H U+S T V A
$$

Teknik analisis data menggunakan analisis deskritif statistik dan moderated regression analysis (MRA). Teknik ini untuk menganalisis moderasi variabelnya.

\section{Hasil dan Pembahasan}

\section{Statistik Deskriptif}

Hasil penelitian menunjukkan bahwa rata-rata profitabilitas perusahaan, baik diukur dengan ROA maupun ROE menunjukkan kinerja yang baik. Demikian juga dengan intellectual capital juga menunjukkan tinggi. Rata-rata nilai perusahaan yang diukur denghan PBV menunjukkan nilai yang positif, hal ini bermakna bahwa ekspektasi investor terhadap perusahaan positif (Tabel 1).

Tabel 1

Statistik Deskriptif

\begin{tabular}{lrrrr}
\hline Variabel & Minimum & Maksimum & Rerata & $\begin{array}{l}\text { Std. } \\
\text { Dev }\end{array}$ \\
\hline ROA & 0,760 & 15,100 & 4,898 & 3,743 \\
ROE & 1,560 & 19,750 & 11,657 & 4,684 \\
VAIC & 0,040 & 8,450 & 3,351 & 1,578 \\
PBV & 0,230 & 5,700 & 2,017 & 1,221 \\
N & 60 & & & \\
\hline
\end{tabular}

Tabel 2

\begin{tabular}{llll}
\multicolumn{4}{c}{ Hasil Analisis Regresi } \\
\hline & $\beta$ & $\mathrm{t}$ & Prob. \\
\hline (Constant) & 0,212 & 0,692 & 0,492 \\
ROA & 0,136 & 3,563 & 0,001 \\
ROE & 0,098 & 3,195 & 0,002 \\
$\mathrm{R}^{2}$ & 0,503 & & \\
$\mathrm{R}^{2}$ Adj & 0,485 & & \\
\hline
\end{tabular}

Variabel terikat: nilai perusahaan

Hasil analisis menunjukkan bahwa profitabilitas, baik yang diukur dengan ROA maupun ROE berpengaruh positif terhadap nilai perusahaan, sehingga $\mathrm{H}_{1}$ diterima. Hal ini menunjukkan bahwa semakin tinggi profitabilitas, maka nilai perusahaan akan semakin meningkat.

Berdasarkan hasil analisis (Tabel 3) menunjukkan bahwa uji interaksi pengaruh ROA terhadap nilai perusahaan dengan intellectual capital sebagai variabel moderasi menunjukkan intellectual capital dapat memoderasi hubungan antara ROA terhadap nilai perusahaan. Sehingga $\mathrm{H}_{2}$ diterima. VAIC juga 
berpengaruh terhadap nilai perusahaan yang ditunjukkan dengan nilai signifikansi 0,033 yang lebih kecil dari 0,05. Sehingga dapat disimpulkan VAIC merupakan varaiabel quasi moderator, yakni variabel yang secara bersamaan menjadi variabel independen dan variabal moderasi.

Hasil uji interaksi pengaruh ROE terhadap nilai perusahaan dengan intellectual capital sebagai variabel moderasi menunjukkan intellectual capital dapat memoderasi hubungan antara ROE terhadap nilai perusahaan. VAIC juga memiliki hubungan dengan nilai perusahaan yang ditunjukkan dengan nilai signifikansi 0,033 yang lebih kecil dari 0,05. maka dapat disimpulkan VAIC merupakan varaiabel quasi moderator, yakni variabel yang secara bersamaan menjadi variabel independen dan variabal moderasi.

Tabel 3

Moderasi Intellectual Capital

\begin{tabular}{lrrr}
\hline & \multicolumn{1}{c}{$\mathrm{t}$} & \multicolumn{1}{c}{ Prob. } \\
\hline (Constant) & 1,392 & 2,409 & 0,019 \\
ROA & 0,469 & 5,161 & 0,000 \\
ROE & $-0,140$ & $-2,015$ & 0,049 \\
VAIC & $-0,383$ & $-2,191$ & 0,033 \\
VAIC_ROA & $-0,101$ & $-3,937$ & 0,000 \\
VAIC_ROE & 0,073 & 3,725 & 0,000 \\
\hline
\end{tabular}

Variabel terikat: nilai perusahaan

\section{Pembahasan}

\section{Profitabilitas terhadap nilai perusahaan}

Variabel ROA dan ROE adalah rasio profitabilitas yang membandingkan antara laba bersih setelah pajak dengan total aktiva perusahaan untuk ROA dan total ekuitas untuk ROE. Semakin besar nilai ROA dan ROE maka semakin baik pula kinerja perusahaan dalam mengelola aset dan modal mereka untuk dijadikan keuntungan bagi perusahaan. Hasil penelitian menunjukkan bahwa variabel profitabilitas yang dicerminkan dengan ROA dan ROE berpengaruh positif signifikan terhadap nilai perusahaan yang tergabung dalam indeks LQ45 tahun 2016-2018. Hasil tersebut mengartikan bahwa apabila profitabilitas perusahaan mengalami kenaikan maka nilai perusahaan juga naik. Rasio ROA dan ROE yang tinggi merupakan keinginan oleh semua pe- rusahaan, jika tingkat ROA dan ROE terus meningkat hal ini mengartikan bahwa perusahaan mempunyai kinerja yang bagus dan berbagai kebijakan serta keputusan yang diambil manajemen perusahaan sangat tepat sehingga menciptakan pemikiran positif dari para investor yang mengakibatkan harga saham akan naik karena permintaannya naik yang mencerminkan nilai perusahaannya tinggi (Husnan \& Pudjiastuti, 2002: 56).

Menurut Wijaya \& Sedana (2015) profitabilitas yang terus meningkat merupakan hasil usaha manajemen yang baik dalam mengelola dana yang telah ditanamkan para investor. Investor akan mendapatkan sinyal positif dari perusahaan apabila rasio ini terus meningkat karena terlihat mempunyai prospek usaha yang baik pada masa yang akan datang.

Hasil penelitian ini sejalan dengan hasil penelitian yang dilakukan oleh Chang \& Hsieh (2011); Mardiyati et al., (2012); Hermuningsih (2012); Dewi et al., (2014); Martini (2014); Sambora (2014); Wang Wang, \& Liang, (2014); Rudangga \& Sudiarta (2016); Novari \& Lestari, 2016), Putra \& Lestari, (2016); Hasibuan et al., (2016); Pertiwi et al., (2016), Pasaribu \& Sulasmiyati (2016); Nurminda, Isynuwardhana, \& Nurbaiti (2017); Ayu \& Suarjaya, (2017); Dhani \& Utama (2017); Suwardika \& Mustanda (2017); Mohammad \& Bujang, (2019); Fristiani et al., (2020); dan Xu \& Liu, 2020) dimana profitabilitas pengaruh positif terhadap nilai perusahaan. Profitabilitas perusahaan yang diproksikan dengan ROA dan ROE yang selalu meningkat setiap periodenya, maka prospek perusahaan sangat menjanjikan. Investor dalam menanamkan modalnya juga akan mengharapkan imbal hasil yang tinggi dan hal tersebut dapat tercermin dari profitabilitas perusahaan, atau dengan kata lain perusahaan yang akan dipilih oleh investor pastilah perusahaan profitable dibanding dengan perusahaan yang tidak profitable.

\section{Moderasi Intellectual Capital pada hubungan Profitabilitas terhadap Nilai Perusahaan}

Berdasarkan hasil penelitian analisis MRA didapatkan hasil bahwa variabel intellectual capital dapat memoderasi hubungan antara profitabilitas terhadap nilai perusahaan- 
perusahaan. Selain itu secara parsial intellectual capital berpengaruh terhadap nilai perusahaan dan secara interaksi juga berpengaruh baik menggunakan interaksi ROA maupun interaksi ROE maka sifat variabel intellectual capital dalam penelitian ini adalah quasi moderator yakni variabel yang dapat menjadi variabel independen dan secara bersamaan juga menjadi variabel moderasi.

Hasil penelitian menunjukkan bahwa investor akan lebih menyukai perusahaan yang dapat membuat atau menciptakan nilai lebih dibanding perusahaan lainnya. Perusahaan yang dapat value added yang lebih dibanding perusahaan lainnya, maka para investor akan mendapatkan keutnungannya juga. Dalam konteks ini penggunaan intellectual capital dapat meningkatkan value added perusahaan tersebut. Jadi perusahaan dapat meningkatkan kinerjanya tidak hanya dengan aset berwujudnya saja, tetapi juga aset tidak berwujudnya. Penggunaan intellectual capital perusahaan akan mendapat respon positif dari pasar sebagai salah satu bentuk apresiasi dan kepercayaan atas pengelolaan perusahaan. Dengan adanya apresiasi tersebut maka akan semakin banyak pula modal yang masuk kedalam perusahaan dan akan membuat perusahaan mencapai nilai yang lebih tinggi dibanding sebelumnya.

\section{Simpulan dan saran}

Kesimpulan dari penelitian ini adalah profitabilitas berpengaruh secara signifikan terhadap nilai perusahaan dengan arah positif, dan variabel intellectual capital dapat memoderasi hubungan antara profitabilitas terhadap nilai perusahaan.

Penelitian ini terbatas pada perusahaan yang masuk LQ 45 dan ukuran profitabilitas hanya menggunakan ROA dan ROE. Untuk peneliti selanjutnya disarankan untuk menggunakan indikator pengukuran yang bisa digunakan dalam perhitungan profitabilitas seperti NPM, OPM, dan GPM yang berpengaruh terhadap nilai perusahaan. Peneliti selanjutnya juga bisa menggunakan objek perusahaan lainnya selain LQ45 sebagai objek penelitian.

\section{Daftra Pustaka}

Astuti, D. (2004). Manajemen keuangan perusahaan. Jakarta: Ghalia Indonesia.

Ayu, D. P., \& Suarjaya, A. A. G. (2017). Pengaruh profitabilitas terhadap nilai perusahaan dengan corporate social responsibility sebagai variabel mediasi pada perusahaan pertambangan. E-Jurnal Manajemen. 6(2). 1112-1138.

Azeez, D. A. A. (2015). Corporate Governance and Firm Performance: Evidence from Sri Lanka. South Asian Journal of Management, 21(1), 180-189. https:/ / doi.org/10.15640/jfbm.v3n1a16

Banamtuan, O., Zuhroh, D., \& Sihwahjoeni, S. (2020). Asset Management and Capital Ownership on Firm Value: Through Profitability. AFRE Accounting and Financial Review, 3(1), 83-92. https://doi.org/10.26905/afr.v3i1.4296

Belkaoui, A. R. (2006). Accounting Theory: Teori Akuntansi. In Jakarta: Salemba Empat. Jakarta: Salemba Empat.

Brigham, E. F., \& Brigham, Eugene F., \& Joel, F. H. (2001). Fundamentals of Financial Management Alih Bahasa Dodo Suharto dan Herman Wibowo, Manajemen Keuangan, Edisi Kedelapan, Buku Satu. Erlangga, Jakarta.

Buallay, A. (2017). The Relationship Between Intelellectual Capital and Firm Perforamnace. Corporate Governance and Organizational Behavior Review, 1(1). https://doi.org/10.22495/cgobr

Chandrarin, G., \& Cahyaningsih, D. S. (2018). Identifikasi Struktur Modal Melalui Profitabilitas, Pertumbuhan Penjualan dan Ukuran Perusahaan. AFRE Accounting and Financial Review, 1(1), 3645.

https://doi.org/10.26905/afr.v1i1.2246

Chang, W. S., \& Hsieh, J. J. (2011). Intellectual Capital and Value Creation-Is Innovation Capital a Missing Link? International Journal of Business and Management, 6(2), 3-12.https://doi.org/10.5539/ ijbm.v6n2p3

Chen, J., Ezzamel, M., \& Cai, Z. (2011). Managerial power theory, tournament 
theory, and executive pay in China. Journal of Corporate Finance, 17(4), 11761199. https://doi.org/10.1016/j.jcorpfin. 2011.04.008

Dewi, P. Y. S., Yuniarta, G. A., AK, S. E., Atmadja, A. T., \& SE, A. (2014). Pengaruh Struktur Modal, Pertumbuhan Perusahaan Dan Profitabilitas Terhadap Nilai Perusahaan Pada Perusahaan LQ 45 Di BEI Periode 2008-2012. JIMAT (Jurnal Ilmiah Mahasiswa Akuntansi) Undiksha, 2(1).

Dewi, P. Y. S., Yuniarta, G. A., AK, S. E., Atmadja, A. T., \& SE, A. (2014). Pengaruh Struktur Modal, Pertumbuhan Perusahaan Dan Profitabilitas Terhadap Nilai Perusahaan Pada Perusahaan LQ 45 Di BEI Periode 2008-2012. JIMAT (Jurnal Ilmiah Mahasiswa Akuntansi) Undiksha, 2(1).

Dhani, I. P., \& Utama, A. A. G. S. (2017). Pengaruh Pertumbuhan Perusahaan, Struktur Modal, dan Profitabilitas terhadap Nilai Perusahaan. Jurnal Riset Akuntansi Dan Bisnis Airlangga, 2(1).

Elfiswandi, Pratiwi, H., \& Melmusi, Z. (2019). The influence of intellectual capital on financial performance:A Study on Banking Companies Listed in Indonesia Stock Exchange. Review of Integrative Business and Economics Research, 8(2), 300-312. https://doi.org/10.2991/ insyma-18.2018.15

Fahmi, I. (2014). Manajemen keuangan perusahaan dan pasar modal. Jakarta: Mitra Wacana Media, 109.

Fristiani, N. L., Pangastuti, D. A., \& Harmono, H. (2020). Intellectual Capital Dan Kinerja Keuangan Terhadap Nilai Perusahaan: Pada Industri Perbankan. AFRE Accounting and Financial Review, 3(1), 35-42. https://doi.org/10.26905/ afr.v3i1.4223

Halim, A. (2005). Analisis investasi. Jakarta: Salemba Empat.

Hamdan, A. (2018). Intellectual capital and firm performance: Differentiating between accounting-based and marketbased performance. International Journal of Islamic and Middle Eastern Finance and Management, 11(1), 139-151.
https://doi.org/10.1108/IMEFM-022017-0053

Haryanto, S. (2014). Identifikasi Ekspektasi Investor melalui Kebijakan Struktur Modal, Profitabilitas, Ukuran Perusahaan dan GCPI. Jurnal Dinamika Manajemen. Jurnal Dinamika Manajemen, 5(2), 183-199. https://doi.org/10.15294/jdm.v5i2.3660 Haryanto, S. (2016). Profitability Identification of National Banking Through Credit, Capital , Capital Structure, Efficiency , and Risk Level. Jurnal Dinamika Manajemen (JDM), 7(1), 11-21.

Haryanto, S., Rahadian, N., Fatima, M., Mbapa, I., Nesty, E., \& Vivi, K. (2018). Kebijakan Hutang, Ukuran Perusahaan dan Kinerja Keuangan Terhadap Nilai Perusahaan: Industri Perbankan di Indonesia. AFRE Accounting and Financial Review, 1(2), 62-70.

Hasibuan, V., Dzulkirom AR, M., \& Wi Endang NP, N. G. (2016). Pengaruh Leverage dan Profitabilitas Terhadap Nilai Perusahaan (Studi pada Perusahaan Property dan Real Estate yang Terdaftar di Bursa Efek Indonesia Periode Tahun 2012-2015). Jurnal Administrasi Bisnis, 39(1), 139-147.

Hermuningsih, S. (2012). Pengaruh profitabilitas, size terhadap nilai perusahaan dengan sruktur modal sebagai variabel intervening. Jurnal Siasat Bisnis, 16(2).

Husnan, S., \& Pudjiastuti, E. (2002). Dasar-dasar Manajemen Keuangan. Yogyakarta: UPP AMP YKPN.

Kasmir. (2010). Pengantar Manajemen Keuangan Lainnya, Lembaga Keuangan. In Jakarta: Kencana Prenada Media Group

Kuspinta, T. D., \& Husaini, A. (2018). Pengaruh Intellectual Capital Terhadap Profitabilitas Perusahaan (Studi Pada Perusahaan Manufaktur yang Terdaftar di Bursa Efek Indonesia Periode Tahun 2014-2016). Jurnal Administrasi Bisnis, 56(1), 164-170.

Mardiyati, U., Ahmad, G. N., \& Putri, R. (2012). Pengaruh kebijakan dividen, kebijakan hutang dan profitabilitas ter- 
hadap nilai perusahaan manufaktur yang terdaftar di Bursa Efek Indonesia (BEI) periode 2005-2010. JRMSI-Jurnal Riset Manajemen Sains Indonesia, 3(1), 117.

Martini, P. D. (2014). Pengaruh Kebijakan Utang Dan Profitabilitas Terhadap Nilai Perusahaan: Kebijakan Dividen Sebagai Variabel Pemoderasi. 3(2).

McGuire, B. J., Schneeweis, T., \& Branch, B. (1990). Perceptions of Firm Quality: A Cause or Result of Firm Performance. Journal of Management, 16(1), 167-180.

Mohammad, H. S., \& Bujang, I. (2019). Performance of Malaysian financial firms: An intellectual capital perspective using MVAIC model. Asian Economic and Financial Review, 9(7), 752-765. https://doi.org/10.18488/journal.aefr.20 19.97.752.765

Novari, P. M., \& Lestari, P. V. (2016). Pengaruh ukuran perusahaan, leverage, dan profitabilitas terhadap nilai perusahaan pada sektor properti dan real estate. E-Jurnal Manajemen, 5(9).

Nurminda, A., Isynuwardhana, D., \& Nurbaiti, A. (2017). The Influence of Profitability, Leverage, and Size Toward Firm Value (Study Of Manufacture Companies Goods And Foods Sub S (Studi Pada Perusahaan Manufaktur Sub Sektor Barang Dan Konsumsi Yang Terdaftar Di Bursa Efek Indonesia Periode 2012-2015). E-Proceeding of Management, 4 (Universitas Telkom), 542-549.

Ozkan, N., Cakan, S., \& Kayacan, M. (2017). Intellectual capital and financial performance: A study of the Turkish Banking Sector. Borsa Istanbul Review, 17(3), 190-198. https://doi.org/10.1016/ j.bir.2016.03.001

Pasaribu, M. Y., \& Sulasmiyati, S. (2016). Pengaruh Struktur Modal, Struktur Kepemilikan Dan Profitabilitas Terhadap Nilai Perusahaan Pada Perusahaan Sektor Industri Dasar Dan Kimia Yang Terdaftar Di Bei Tahun 2011-2014. Jurnal Administrasi Bisnis, 35(1), 154-164.

Pertiwi, P. J., Tommy, P., \& Tumiwa, J. R.
(2016). Pengaruh Kebijakan Hutang, Keputusan Investasi Dan Profitabilitas Terhadap Nilai Perusahaan Food And Beverages Yang Terdaftar Di Bursa Efek Indonesia. Jurnal EMBA: Jurnal Riset Ekonomi, Manajemen, Bisnis Dan Akuntansi, 4(1).

Prasetyorini, F., \& Fitri, B. (2013). Pengaruh ukuran perusahaan, leverage, price earning ratio dan profitabilitas terhadap nilai perusahaan. Jurnal Ilmu Manajemen (JIM), $1(1)$.

Putra, A. A. N. D. A., \& Lestari, P. V. (2016). Pengaruh Kebijakan Dividen, Likuiditas, Profitabilitas dan Ukuran Perusahaan Terhadap Nilai Perusahaan. E-Jurnal Manajemen, 5(7).

Poh, L. T., Kilicman, A., Nur, S., Ibrahim, I., Poh, L. T., Kilicman, A., ... Ibrahim, I. (2018). On intellectual capital and financial performances of banks in Malaysia On intellectual capital and financial performances of banks in Malaysia. Cogent Economics \& Finance, 16(1). https:// doi.org/10.1080/23322039. 2018.1453574

Pulic, A. (2000). VAICT-an accounting tool for IC management. International Journal ofTechnology Management. Vol. 20 Nos 5/6/7/8: 702-71

Ramadhan, M. I. B., Abdurahim, A., \& Sofyani, H. (2019). Modal Intelektual Dan Kinerja Maqashid Syariah Perbankan Syariah Di Indonesia. Jurnal Akuntansi Dan Keuangan Islam, 6(1), 5-18. https://doi.org/ 10.35836/jakis.v6i1.6

Rudangga, I. G. N. G., \& Sudiarta, G. M. (2016). Pengaruh ukuran perusahaan, leverage, dan profitabilitas terhadap nilai perusahaan. E-Jurnal Manajemen, 5(7).

Sambora, M. N. (2014). Pengaruh Leverage dan Profitabilitas Terhadap Nilai Perusahaan (Studi pada Perusahaan Food and Beverages yang Terdaftar di BEI Periode Tahun 2009-2012). Jurnal Administrasi Bisnis, 8(2).

Sari, P. I. P., \& Abundanti, N. (2014). Pengaruh pertumbuhan perusahaan dan leverage 
terhadap profitabilitas dan nilai perusahaan. E-Jurnal Manajemen, 3(5).

Septiani, E., Holiawati, \& Ruhiyat, E. (2019). Environmental Performance, Intellectual Capital, Praktik Penghindaran Pajak Dan Nilai Perusahaan. Jurnal Bisnis Dan Akuntansi, 21(1), 61-70.

Sudana, I. M. (2015). Teori dan Praktik Manajemen Keuangan Perusahaan. Jakarta: Erlangga.

Suwardika, I. N. A., \& Mustanda, I. K. (2017). Pengaruh leverage, ukuran perusahaan, pertumbuhan perusahaan, dan profitabilitas terhadap nilai perusahaan pada perusahaan properti. E-Jurnal Manajemen, 6(3), 1248-1277.

Suwarjuwono, T., \& Kadir, A. P. (2003). Intellectual Capital: Perlakuan, Pengukuran dan Pelaporan (sebuah Library Research). Jurnal Akuntansi Dan Keuangan, 5(1), 31-51.

$\mathrm{Xu}$, J., \& Liu, F. (2020). The Impact of Intellectual Capital on Firm Performance: A Modified And Extended VAIC Model. Journal of Competitiveness, 12(1), 161-176. 